\title{
The exact publication date in Arthropoda Selecta - what does this mean?
}

\section{Точная дата пубцикации Arthropoda Selecta - что это означает?}

\author{
Kirill G. Mikhailov ${ }^{1}$, Sergei I. Golovatch ${ }^{2}$ \\ К.Г. Михайлов ${ }^{1}$, С.И. Головач²

\begin{abstract}
${ }^{1}$ Zoological Museum MGU, Bolshaya Nikitskaya Str., 2, Moscow 125009 Russia. E-mail: mikhailov2000@gmail.com
1 Зоологический музей МГУ, ул. Большая Никитская, 2, Москва 125009 Россия.

${ }^{2}$ Institute for Problems of Ecology and Evolution, Russian Academy of Sciences, Leninsky prospekt 33, Moscow 119071 Russia. E-mail: sgolovatch@yandex.ru

${ }^{2}$ Институт проблем экологии и эволюции РАН, Ленинский проспект, 33, Москва 119071 Россия.
\end{abstract}

KEY WORDS: nomenclature, priority, scientific journals.

КЛЮЧЕВЫЕ СЛОВА: номенклатура, приоритет, научные журналы.

ABSTRACT. Provision of the exact publication dates for the papers that have appeared and are to appear in Arthropoda Selecta is discussed and shown to strictly follow ICZN Article 21.3. In this connection, the recent rebuttal by Zhao [2019], who, manipulating with publications dates, argued and even reversed the synonymy of two species of Linyphiidae, appears to be superfluous and useless, the correct synonymy of $\mathrm{Na}$ soonaria circinata Zhao et Li, 2014 under $N$. magna Tanasevitch, 2014, and that of Theoa bidentata Zhao et Li, 2014 under Th. elegans Tanasevitch, 2014, being reinstated.

How to cite this article: Mikhailov K.G., Golovatch S.I. 2020. The exact publication date in Arthropoda Selecta - what does this mean? // Arthropoda Selecta. Vol.29. No.1. P.151-153. doi: 10.15298/arthsel. 29.1.14

РЕЗЮМЕ. Показано, что приведение точных дат публикации работ в журнале Arthropoda Selecta полностью соответствует требованиям статьи 23.1 Международного кодекса зоологической номенклатуры. В этой связи опровергнута недавняя попытка Zhao [2019] оспорить и даже перевернуть с ног на голову на основании манипуляций с датами публикации синонимию Nasoonaria circinata Zhao et Li, 2014 к N. magna Tanasevitch, 2014, a Theoa bidentata Zhao et Li, 2014 к Th. elegans Tanasevitch, 2014.

Article 21 of ICZN [1999] strongly recommends the publishers to provide an exact publication date for any taxonomic paper. In the journals of KMK Scientific Press, such as Arctoa, Arthropoda Selecta, Russian Entomological Journal, Russian Journal of Theriology, Euroasian Entomological Journal and Invertebrate Zoology, as well as in the earlier issues of Acarina (presently no longer belonging to KMK), lots of taxonomic papers have already appeared and lots of new ones are regularly being printed. Provision of the exact publica- tion dates has been recognized as essential both by the editorial boards and KMK since the early 1990's. This has resulted in clearly and simultaneously dating any paper to appear, both printed and electronic versions.

In Arthropoda Selecta, Russian Entomological Journal and the other journals of KMK Scientific Press that contain taxonomic stuff, publication dates have been shown in several ways. Initially, only the month was provided on the back of the title page in Arthropoda Selecta and Russian Entomological Journal, both since 1992 , vs. on the inner cover page in Russian Journal of Theriology (since 2002) or on the back cover page in Invertebrate Zoology (since 2004). This tradition is followed up to now.

Later in 1998, special lines or even pages (since 2015) were created in printed copies of Arthropoda Selecta and Russian Entomological Journal with dayto-day printing data for earlier issues (Figs 1,2). Since 2001, such data have been provided in elibrary.ru (missing in the current version).

At the beginning of 2013, all information concerning the KMK journals, mainly Arthropoda Selecta and Russian Entomological Journal, including exact publication dates, appeared on the official site of the Zoological Museum, Moscow State University: http:// zmmu.msu.ru/spec/publikacii/zhurnali. Since then, pdf versions of the papers have been uploaded simultaneously with the appearance of the journals' printed versions.

The current website for the KMK Scientific Press journals (kmkjournals.com) was launched in 2014. Publication dates were and still are indicated on special pages, https://kmkjournals.com/journals/AS/AS Exact Publ_Dates, Arthropoda Selecta taken as an example. Because this information, together with printed dates (like in Fig. 2), clearly and unequivocally shows the appearance of any paper, strictly in accordance with ICZN Article 21.3, we see no reason to follow ICZN Article 21.3.1 which refers to the end of the 


\section{Information. Announcements. Информация. Объявления}

Announcements. Titles to appear in forthcoming issues of Arthropoda Selecta: Phylogeny and system of the Arthropoda, by Ya.I. Starobogatov; Arthropod evolution from apody to myriapody, as paraphylectic walk with homeotic and neotenic steps, by D.E. Shcherbakov; A new species of the genus Pseudocrangonyx Akatsuka et Komai (Crustacea Amphipoda) from the subterranean fresh waters on the Island Sakhalin, by V.S. Labay; Some crangonid shrimps of the Toza Bay, Japan, by R.N. Burukovsky; A record of South African deep water lobster Palinurus unicormutus Berry, 1979 (Crustacea Decapoda Palinuridae) in the waters off Kenya, by $V . V$. Timofeev \& Yu.V. Korzun; Notes on variability and distribution of five species of hermit crabs (Crustacea Decapoda Paguridae) in the Norwegian Sea, by V.I. Sokolov; Taxonomically interesting records of the swimming crabs (Crustacea Decapoda Portunidae) in the Indian Ocean considerably extending known ranges of species, by V.A. Spiridonov; An update of the swimming crabs (Crustacea Decapoda Portunidae) in the western Indian Ocean, by V.A. Spiridonov; Solpugids of Turkmenistan, by A.V. Gromov; Remarks on the Ural spider fauna, 8, by S.L. Esyunin \& V.E. Efimik; A new species of the mygalomorph genus Atypus from Russian Far East, by T.I. Oliger; Spiders of the genusPholcusfrom Maritime Province, Russian Far East, by T.I. Oliger; Miscellaneous notes on the Middle Asian jumping spiders (Aranei Salticidae), by D. V. Logunov \& S.Yu. Rakov; On the jumping spider fauna of the southern part of West Siberia (Aranei Salticidae), by S.Yu. Rakov; Notes on the spider genus Styloctetor Simon, 1884 and some related genera, with description of two new species from Siberia (Aranei Linyphiidae), by Yu.M. Marusik \& A.V. Tanasevitch.

Взносы в Евразиатское Арахнологическое Общество определены в размере 5000 (5) рублей за 1997 и 1998 годы для лиц, проживающих на территории СНГ. Взносы просьба пересылать почтовыми переводами секретарю Общества К.Г.Михайлову.

Журнал "Actias", выходивший в 1994-1995 гг., объединен с журналом Russian Entomological Journal. Статьи по чешуекрылым, принятые к публикации в третьем томе "Actias", будут опубликованы в шестом Russian Entomological Journal за 1997 год.

Даты выхода в свет последних номеров журналов КMK Scientific Press:

Arthropoda Selecta, vol.6 (1997), no.1/2 - 30 декабря 1997 г.

Стоимость подписки на зоологические журналы издания KMK Scientific Press на 1998 год:

Arthropoda Selecta - 100 руб. для частных лиц и 120 руб. для организаций,

Russian Entomological Journal - 100 руб. для частных лиц и 120 руб. для организаций,

Acarina - 20 руб. для частных лиц и 50 руб. для организаций

Можно приобрести номера журналов прошлых годов выпуска.

Имеется в продаже книга С.Л. Есюнина и В.Е. Ефимика "Каталог пауков Урала" (1996), цена 30 руб., а также книга К.Г. Михайлова "Каталог пауков территорий бывшего СССР" (1997), цена 40 руб. Летом 1998 г. планируется выпустить дополнение ко второму каталогу. Запросы направлять К.Г. Михайлову.

Просьба переводить подписку на имя Михайлова Кирилла Глебовича по адресу:

103009 Россия, Москва К-9,

ул. Большая Никитская (бывш. Герцена) 6,

Зоологический музей МГУ

Тел. раб. (7-095)292-5796

Факс ～(7-095)203-2717

E-mail kmk2000@glas.apc.org

Fig. 1. First reference to the exact publication date (shown in a box) on a general information page, Arthropoda Selecta printed version, vol.6 (for 1997), nos 3-4 (printed in 1998).

Рис. 1. Первая ссылка на точную дату публикации (показано в рамке) на общей информационной странице в печатной версии Arthropoda Selecta, т.6 (за 1997), вып.3-4 (1998).

publication month. If need be and in the case of a particularly deep mistrust, the date of the deposition of each printed copy of any journal at the Library of the Zoological Museum in Moscow, where both KMK and any of its periodicals belong, could easily be verified by writing there directly.

A very surprising paper has recently been published by Zhao [2019], who, manipulating with publication dates, argued, refuted and reversed the synonymy of two linyphiid spider species, Nasoonaria magna
Tanasevitch, 2014 and Theoa elegans Tanasevitch, 2014, both described from Thailand [Tanasevitch, 2014] and both subsequently [Tanasevitch, 2016] considered as subjective senior synonyms of Nasoonaria circinata Zhao et Li, 2014 and Theoa bidentata Zhao et Li, 2014, respectively. Both latter taxa were described from a tropical part of Yunnan, China. Because the paper by Zhao \& Li [2014] appeared on December $4^{\text {th }}$, 2014, whereas that by Tanasevitch [2014] on December $2^{\text {nd }}, 2014$, only two days earlier, Tanasevitch's 


\section{Exact publication dates of Arthropoda Selecta issues}

\begin{tabular}{|c|c|c|c|}
\hline Vol.1 (for 1992): & 2061092 & no $2-071992$ & 30121007 \\
\hline Vol.2 (for 1993): & no.1 - 04.1993, & no. $2-06.1993$, & no. $3-09.1993$ \\
\hline Vol.3 (for 1994): & nos $1-2-22.08 .1994$, & & nos $3-4-4.04 .1995$. \\
\hline Vol.4 (for 1995): & no. $1-15.06 .1995$ & no. $2-13.06 .1995$, & nos $3-4-25.01 .1996$. \\
\hline Vol.5 (for 1996): & nos 1-2 - 09.1996, & & $\operatorname{nos} 3-4-6.01 .1997$ \\
\hline Vol.6 (for 1997): & $\operatorname{nos} 1-2-30.12 .1997$, & & $\operatorname{nos} 3-4-9.06 .1998$. \\
\hline Vol.7 (for 1998): & no. $1-29.09 .1998$ & no. $2-23.11 .1998$ & no. $3-24.03 .1999$ \\
\hline Vol.8 (for 1999): & no.1 - 5.11.1999, & no. $2-28.12 .1999$, & no. $3-2.03 .2000$ \\
\hline Vol.9 (for 2000): & no. $1-20.11 .2000$ & no. $2-19.02 .2001$, & no. $3-16.04 .2001$ \\
\hline Vol.10 (for 2001): & no. $1-8.10 .2001$ & no. $2-7.02 .2002$ & no. $3-20.07 .2002$, \\
\hline Vol.11 (for 2002): & no. $1-14.01 .2003 ;$ & no. $2-5.03 .2003$, & no. $3-9.07 .2003$ \\
\hline Vol.12 (for 2003): & no.1 - 27.12.2003; & no. $2-28.022004$, & $\operatorname{nos} 3-4-16.07 .2004$ \\
\hline Vol.13 (for 2004): & $\operatorname{nos} 1-2-22.10 .2004$; & no. $3-15.03 .2005$, & no. $4-30.06 .2005$ \\
\hline Vol.14 (for 2005): & no.1 - 20.07.2005; & no. $2-27.12 .2005$, & no. $3-23.03 .2006$, \\
\hline Vol.15 (for 2006): & no. $1-30.11 .2006$ & no. $2-23.03 .2007$, & no. $3-16.07 .2007$, \\
\hline Vol.16 (for 2007): & no. $1-28.12 .2007$ & no. $2-18.04 .2008$ & no. $3-20.08 .2008$, \\
\hline Vol.17 (for 2008): & no.1-2 - 30.12.2008; & no. $3-4-5.04 .2009$ & \\
\hline Vol.18 (for 2009): & no.1-2-21.10.2009; & no. $3-4-30.12 .2009$. & \\
\hline Vol.19 (for 2010): & no. $1-15.04 .2010$ & no. $2-10.06 .2010$ & no. $3-30.09 .2010$; \\
\hline Vol.20 (for 2011): & no. $1-30.03 .2011$ & no. $2-7.07 .2011$ & no. $3-9.09 .2011$ \\
\hline Vol.21 (for 2012): & no. $1-23.03 .2012 ;$ & no. $2-25.06 .2012$ & no. $3-8.10 .2012$ \\
\hline Vol.22 (for 2013): & no. 1 - 25.03.2013; & no. $2-5.06 .2013$ & no. $3-26.08 .2013$ \\
\hline Vol.23 (for 2014): & no. 1 - 13.03.2014; & no. $2-5.04 .2014$, & no. $3-3.09 .2014$ \\
\hline
\end{tabular}

no. $4-03.1993$ no. $4-14.03 .1994$.

no. $4-2.07 .1999$. no. $4-8.06 .2000$. no. $4-20.07 .2001$. no. $4-25.10 .2002$. no. $4-14.10 .2003$.

no.4-31.07.2006. no. $4-23.11 .2007$. no. $4-10.12 .2008$.

no. $4-30.12 .2010$. no. $4-22.12 .2011$. no. $4-27.12 .2012$. no. $4-6.12 .2013$ no. $4-2.12 .2014$

Fig. 2. Page containing the first exact publication dates, Arthropoda Selecta printed version, vol.24, no.1 (2015).

Рис.2. Страница, впервые показывающая точные даты публикаций, в печатной версии Arthropoda Selecta, т.24, вып.1 (2015).

[2016] synonymization naturally followed the Code's rules of publication date priority, however minor, and established that both Nasoonaria magna and Theoa elegans be the proper species names to use. Although it is understandably hurtful for Zhao [2019] to see the names Nasoonaria circinata and Theoa bidentata sunken under Nasoonaria magna and Theoa elegans, respectively, the arguments he put forth to justify the reverse synonymy and the priority of Nasoonaria circinata and Theoa bidentata over Nasoonaria magna and Theoa elegans, respectively, are definitely wrong. The very fact of synonymy thereby remains unquestioned on both sides.

Our reasons to retain and confirm the publication date of Tanasevitch's [2014] paper as being December $2^{\text {nd }}, 2014$ are as follows: (1) strict coincidence of the publication dates of electronic and paperwork versions in Arthropoda Selecta and other KMK scientific journals; (2) existence of both electronic and paperwork lists of publication dates of the journals. It is Zhao's [2019] claim that has prompted us to clarify the situation and to present our rebuttal. But as we do strictly follow the provisions of ICZN Article 21.3, the publication dates of KMK journals may not be questioned.

To summarize, Tanasevitch [2014] was published exactly as stated on the website of the periodical, on
December $2^{\text {nd }}, 2014$, both online and in print. Because there are no real grounds to mistrust this readily available information, the revisionist paper by Zhao [2019] is simply to be ignored and discarded as completely superfluous and useless. Colleague Zhao must simply admit his bad luck!

\section{References}

International Code of Zoological Nomenclature. 2020. $5^{\text {th }}$ Edition. http://iczn.org/the-code/the-international-code-of-zoologicalnomenclature/the-code-online (accessed March 22 $2^{\text {th }}, 2020$ ).

Tanasevitch A.V. 2014. On the linyphiid spiders from Thailand and West Malaysia (Arachnida: Aranei: Linyphiidae) // Arthropoda Selecta. Vol.23. No.4. P.393-414.

Tanasevitch A.V. 2016. A case of disjunct montane linyphiid species (Araneae) in the Palaeotropics, with notes on synonymy and the description of a new species // Revue suisse de Zoologie. Vol.123. No.2. P.235-240.

Zhao Q.Y. 2019. Online but unofficially published: new synonyms of two linyphiid spiders // Acta Arachnologica Sinica. Vol.28. No.2. P.128-130.

Zhao Q.Y., Li S.Q. 2014. A survey of linyphiid spiders from Xishuangbanna, Yunnan Province, China (Araneae, Linyphiidae) // ZooKeys. Vol.460. P.1-181.

Responsible editor Yu.M. Marusik 